\title{
Identification of a mitotic recombination hotspot on chromosome III of the asexual fungus Aspergillus niger and its possible correlation with elevated basal transcription
}

Peter J. I. van de Vondervoort • Sandra M. J. Langeveld · Jaap Visser •

Noël N. M. E. van Peij · Herman J. Pel • Cees A. M. J. J. van den Hondel •

Arthur F. J. Ram

Published online: 2 October 2007

(c) Springer-Verlag 2007

Erratum to: Curr Genet (2007) 52:107-114

DOI 10.1007/s00294-007-0143-0

The original version of this article unfortunately contained a mistake. In the title of the original publication the word "with" is missing. The correct title is given below.

Identification of a mitotic recombination hotspot on chromosome III of the asexual fungus Aspergillus niger and its possible correlation with elevated basal transcription

The online version of the original article can be found under doi:10.1007/s00294-007-0143-0.

P. J. I. van de Vondervoort · S. M. J. Langeveld ·

C. A. M. J. J. van den Hondel · A. F. J. Ram ( $₫)$

Institute of Biology, Leiden University,

Wassenaarseweg 64, 2333 AL Leiden, The Netherlands

e-mail: A.F.J.Ram@biology.leidenuniv.nl

URL: http://biology.leidenuniv.nl/ibl/S4/aboutF.shtml

P. J. I. van de Vondervoort

e-mail: Peter.Vondervoort-van-de@dsm.com

J. Visser

FGT Consultancy, P.O. Box 396,

6700 AJ Wageningen, The Netherlands

P. J. I. van de Vondervoort · N. N. M. E. van Peij · H. J. Pel

DSM Food Specialties, P.O. Box 1, 2600 MA Delft,

The Netherlands

URL: http://www.dsm.com/nl_NL/html/dfs/home.htm 